International Journal of Social Science And Human Research

ISSN(print): 2644-0679, ISSN(online): 2644-0695

Volume 05 Issue 01 January 2022

DOI: 10.47191/ijsshr/v5-i1-22, Impact factor-5.586

Page No: 145-149

\title{
Evaluation in Sports Achievement Development: Literature Review
}

\author{
Syahrizal Emil Rahman \\ Physical Education, Postgraduate, Jakarta State University, Indonesia
}

\begin{abstract}
Coaching sports achievement requires a coaching process that starts from the club. The coaching process requires good management at the club in order to obtain results in an effective and efficient manner. Good and efficient management in managing a sports club in the context of its achievement is decisive. This study aimed to determine Evaluation in Sports Achievement Development. The method used is literature study or literature review. A literature study is a research design used in collecting data sources related to a topic. It collects data for the study of literature using a database to search for literature sources. Data collection used the Reporting Items for Systematic Review and Meta-Analysis (PRISMA) method. From the results of research and discussion, it can be concluded that athlete breeding can be done by carrying out talent identification and then continuing with the talent development stage. This method is expected to make the nursery process better. The nursery system used in the concept of sports coaching is a nursery system that is able to become the foundation of achievement development. A good foundation is at school age where educational sports are important to give birth to athlete seeds.
\end{abstract}

KEYWORDS: Evaluation, Sports Achievement

\section{INTRODUCTION}

Sport is an activity that is part of human physical activity, because doing physical activity has the intent and purpose to improve the quality of life (Jian Andri Kurniawan et al., 2015). Evaluation comes from English, namely evaluation. The word evaluation is absorbed from the Indonesian term with the aim of maintaining the original word with a slight adjustment of Indonesian pronunciation so that it becomes an evaluation (Suharsimi Arikunto, 2010). Evaluation is a series of activities carried out intentionally to see the level of program success (Supriadi., 2019). The program evaluation carried out is expected to reduce the obstacles that exist in the implementation of the training program. Evaluation is a process that determines to what extent the objectives can be achieved. Usually evaluation is always associated with learning outcomes, but now the concept of evaluation has a broader meaning (Tayibnapis, 2008).

Evaluation is a program that involves various units containing policies and a series of activities that must be carried out at a certain time, then evaluation is an activity to collect information about the workings of an activity, then the information is used to determine the right alternative in making decisions or evaluating the same meaning as activities supervision. While the program is a plan that involves various units containing policies and a series of activities that must be carried out in a certain period of time, then evaluation is an activity to collect information about the work of an activity, which further information is used to determine the right alternative in making decisions or evaluating the same This means that with supervision activities, supervision or evaluation activities that are intended to make decisions to follow up on programs that have been implemented.

(Ayu Reza Adzalika, Soegiyanto, 2019) in a systematic, planned, organized and sustainable coaching process requires evaluation since through evaluation any field work can be evaluated and categorized as good or bad. Evaluation is considered as a process that determines the achievement of the objectives of the planned activities. Evaluation is focused on an activity within a particular unit. These activities can be in the form of programs, processes or work results, places, organizations or institutions. While the program is a system that is not carried out only once but continuously (Tangkudung, 2018).

This research is expected to provide information to trainers regarding the importance of training programs in the coaching process. Thus the coach has the motivation to make the right training program according to the characteristics of the athlete in order to achieve maximum performance. This research is expected to provide information to athletes about the importance of following instructions from coaches in training and motivate athletes to continue to develop their achievements for maximum performance. For Organizational Management, this research is expected to be able to provide information and input to organizational management regarding how the coaching has been implemented, which can later be used as a reference to develop and improve coaching for the better. 


\section{Evaluation in Sports Achievement Development: Literature Review}

\section{METHODS}

The method used is literature study or literature review. A literature study is a research design used in collecting data sources related to a topic. The literature study aims to describe the main content based on the information obtained (Herliandry et al., 2020). Data collection is carried out using a database to search for literature sources. This data collection uses the Preferred Reporting Items for Systematic Reviews and Meta-Analysis (PRISMA) method. The research was carried out by analyzing journals and then making a summary related to the study objectives. The journal search procedure has the PICOT procedure criteria. The PICOT method has been extended to the questions used to review journals. Researchers conducted a review of journals in the last ten years. The strategies used in the literature search were collected from national and international journal providers' databases. The national and international journal providers database can be accessed through several websites. The access used to search for the articles reviewed is Google Scholar, Eric, and Scopus.

\section{RESULTS AND DISCUSSION}

\section{Evaluation Purpose}

The purpose of evaluation is to obtain accurate and objective information about a program. The information can be in the form of program implementation processes, impacts with the results achieved. Efficiency and utilization of evaluation results focused on the program itself, namely to make a decision whether to continue, improve or discontinue. In addition, it is also used for the purpose of preparing the next program as well as formulating policies related to the program (Connie Chairunnisa, 2011).

(Helen Purnama Sari, 2017) The purpose of the evaluation is to determine the improvement of a program in achieving the internal goals of the institution or institution, to be considered for decision making and accountability for tasks to stakeholders. While the evaluation is to find out the achievement of the objectives of a program that is set at the beginning of the preparation of the program, there are two objectives of implementing the evaluation, namely general objectives and specific objectives, in general, the purpose of evaluation research is to find out how effective the program has been. Then the specific purpose of evaluation research is to find out how much the performance of each component is as an important factor to support a process with the results achieved.

According to (Satria \& Muba, 2012) a systematic, planned, regular, and continuous coaching process needs to be evaluated because a field of work can be known to be good or bad if an evaluation has been carried out. The objectives of evaluating a program include: 1) communicating the program to the public, 2) providing information for decision makers, 3) improving existing programs, and 4) increasing participation.

\section{Evaluation Benefits}

Evaluation is an effort to conduct a review to provide guidance. So program evaluation is the first step in providing guidance, among others, collecting the right data so that it can be continued with the provision of proper coaching as well.

According to (Suharsimi Arikunto, 2010) there are four possible policies that can be carried out based on the results in the implementation of a decision program, namely

a. Stopping the program, because it has no benefit or cannot be implemented as expected.

b. Revise the program, because there are parts that are not in line with expectations.

c. Continue the program, because the implementation of the program shows that everything has gone according to expectations and is delivering results.

d. Disseminate the program, because the program is successful.

3. Evaluation Model

\section{a. Evaluation of the Provus Model (Discrepancy Model)}

The word discrepancy means gap, this model according to (D. C. Stufflebeam \& Coryn, 2014) is based on the assumption that to determine the feasibility of a program, evaluators can compare what should be expected to happen (standard) with what actually happened (performance). By comparing the two things, it can be seen whether there is a discrepancy, namely the standard set with the actual performance. This model was developed by Malcolm Provus, aiming to analyze a program whether the program deserves to be continued, improved, or discontinued. This model emphasizes the formulation of standards, performance, and discrepancy in a detailed and measurable manner. Program evaluations carried out by evaluators measure the size of the gaps that exist in each program component. With the elaboration of gaps in each component of the program, corrective steps can be clearly taken.

\section{b. Responsive Stakes Model}

According to (Stake, 2005) has outlined several characteristics of the responsive evaluation model approach, namely:

(1) More towards program activities (processes) than program goals.

(2) Having relationships with many groups to get evaluation results.

(3) The difference in the value of the perspective of many individuals becomes a measure in reporting the failure and success of a program. 


\section{Evaluation in Sports Achievement Development: Literature Review}

This approach is a system that sacrifices some facts in the evaluation in the hope of increasing the use of the evaluation results to the individual or the program itself. This model is based on what individuals usually do to judge a case. To carry out this evaluation, evaluators are forced to work harder to ensure the selected individual understands what needs to be done. Evaluators also need to establish standard procedures and find and organize a team to pay attention to the implementation of the program. With the help of the team, the evaluator will provide notes, descriptions, results of objectives and create graphs.

The stages, namely:

(1) The initial implementation of the evaluation, the evaluator and the client (stakeholder) make negotiations on the contract regarding the purpose of the assessment, validity and assurance of confidentiality.

(2) Identify the concerns, issues and values of stakeholders.

(3) Collecting information related to goals, issues, values that are identified by stakeholders.

(4) Provision of reports regarding decisions or alternatives. This report contains several issues and concerns that are well known to stakeholders.

\section{c. Tyler's Goal Attainment model}

The Goal Attainment evaluation model is a simple evaluation model. The evaluation's emphasis on the outcome aspect alone makes the evaluation easier to understand, follow and implement. This evaluation model has been simulated for years resulting in refined actions and instruments. Goal attainment models are the work of Ralph Tyler. This model emphasizes the importance of specific goals for each educational process and evaluation is emphasized to find out how far the targeted goals have been achieved.

The objective-oriented evaluation literature is extensive, and is filled with creative ideas for applying this approach. Weaknesses of the Goal Attainment Evaluation Model.

(1) Ignoring the planning and process aspects of the learning process.

(2) The discrepancy between the level of objectives and their implementation.

\section{d. Stake's Countenance Model}

According to the characteristics of the problem in the field, what is considered appropriate and relevant to the problem to be evaluated is an option for researchers to apply the Countenance Evaluation Model. The choice of this model is due to the strength of this evaluation model, namely the evaluation process of planning, process and results that are very suitable to the problems of this research.

According to (Connie Chairunnisa, 2011) the countenance evaluation model, which was developed by the stake. This model emphasizes the implementation of two main things, namely 1) description and 2) judgments, and distinguishes the three stages in program evaluation, namely: 1) antecedents (anteced-ent/context), 2) transition (transaction/process) and 3) results (outputs)

According to (Stake, 2005), the model evaluation countenance is an attempt to describe programs and give judgment to them. Evaluation of countenance is an approach to evaluate the evaluation of education and other programs. Referring to this, the appropriate evaluation model in this study is the countenance stake evaluation model. The countenance stake model consists of two matrices. The first matrix is called the description matrix and the second is called the consideration matrix. The new consideration matrix can be done by the evaluator after the description matrix is completed.

According to (Stake, 2005), evaluation of the stake model provides a full description and consideration of learning. In this model, stakes emphasize the role of evaluators in developing learning objectives into specific and measurable goals. The description matrix consists of categories of goals (intents) and observations. The consideration matrix consists of standard categories and considerations. In each category there are three focuses:

(1) Antecedent (context) A condition that exists before the instruction that relates to the result

(2) Transaction (process) which is an activity instruction process

(3) Outcomes (results), namely the effects of experience, observations and work results

According to (Tayibnapis, 2008) that the analysis of the evaluation process proposed by Stake brought a considerable impact in the field of evaluation and laid a simple foundation but is a strong enough concept for further developments in the field of evaluation. Stake emphasizes that there are two basic activities in evaluation, namely (1) description and (2) judgments; and distinguish between three stages in program evaluation, namely (1) antecedents (antecedents/context), (2) transactions (transactions/processes), and (3) outputs (outcomes).

Another factor that becomes the basis for choosing the Countenance Evaluation Model is in its assessment of the needs of the program served by the evaluator. In addition, efforts to describe the complexity of the program as a reality that may occur and have great potential to gain new insights and theories about the field and program that will be evaluated.

\section{e. CIPP Evaluation Model}

The evaluation model is an evaluation design model created by experts or evaluation experts who are usually named the same as the maker. In the implementation of evaluation, we hear many evaluation models, usually the evaluation model used is adjusted to 


\section{Evaluation in Sports Achievement Development: Literature Review}

the type of object being evaluated or adapted to needs. However, in the world of sports, the evaluation model that is commonly used is the CIPP (context, input, process, product) evaluation model.

The CIPP evaluation model is a model developed by (D. C. Stufflebeam \& Coryn, 2014) this model refers to four stages of evaluation: context evaluation, input evaluation, process evaluation and product evaluation. This is based on the view that the most important objective of evaluation is to improve the functioning of a program, this is in line with the opinion (Topno Harshit, 2012) which says that "It refers to the four phases of evaluation: context evaluation, input evaluation, process evaluation and product evaluation. It is based upon the view that the most important purpose of evaluation is to improve the functioning of a programme".

What is meant by this evaluation is an evaluation approach that is oriented towards decision makers to provide assistance to administrators or decision makers (Zapata, 2015). The CIPP model is a comprehensive framework for guiding formative and summative evaluation of projects, programs, personnel, products, institutions, and systems". The CIPP model is comprehensive to guide the evaluation of formative and summative frameworks for programs and so on. In addition, the CIPP evaluation model is one of the most widely used models in program evaluation.

(Hakan \& Seval, 2011) explains that "One of the strengths of the CIPP model is, especially, that it is a useful and simple tool for helping evaluators produce questions of vital importance to be asked in an evaluation process. Evaluators can determine lots of questions for each component of the CIPP model". One of the strengths of the CIPP model is that it is a simple tool to help evaluators generate very important questions to ask in the evaluation process. The evaluator can assign multiple questions to each component of the CIPP model.

The CIPP model is often said to be an evaluation model that has a comprehensive evaluation format at each stage. In each of its components, this model has its own emphases and goals but they all complement each other.

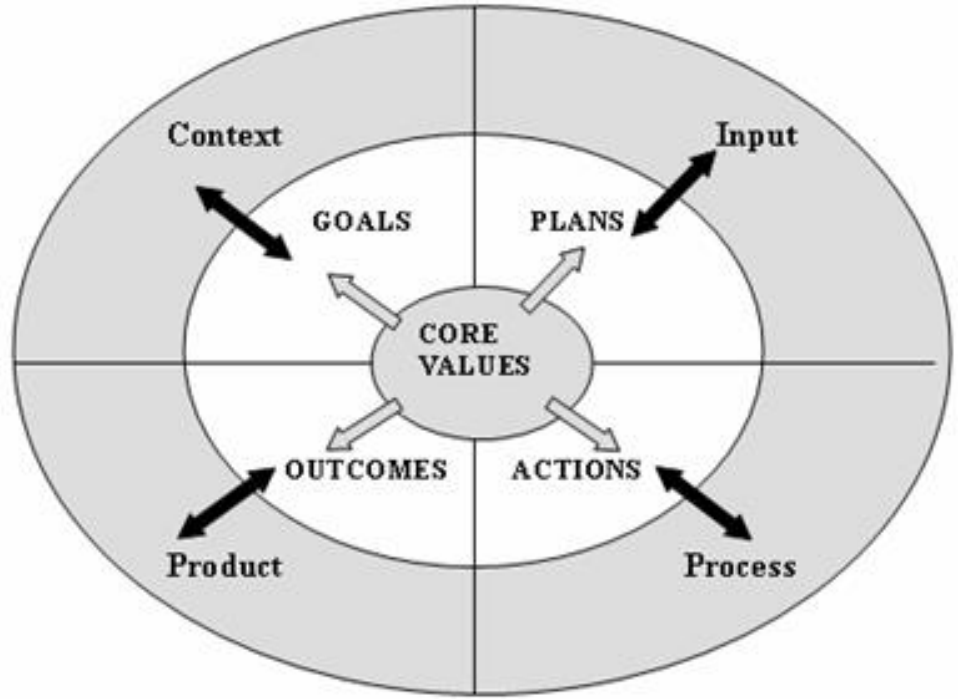

Figure 1. Components of the CIPP Evaluation Model

Source : (D. L. Stufflebeam, 2015)

\section{Sports Achievement Development}

The development of early childhood sports achievement can be done systematically. Therefore, proper breeding of prospective athletes is carried out from an early age (Meiyanto et al., 2018). Coaching sports achievement requires a series of coaching processes that start from the club. The coaching process requires good management within the club in order to obtain results in an effective and efficient manner. Good and efficient management in managing sports club activities in the context of achievement of its role is so decisive. Increasing the attention of sports coaches, the press and those in the academic world to the issue of sports coaching.

The problem is acquiring skills and fitness on a multilateral basis and specialization. The objective of the problem is to involve as many prospective athletes as possible in sports achievements as part of increasing national sports achievements. Human resources (HR) are a basic prerequisite for the development process of all fields. The productivity aspect of development can be realized due to the availability of quality and adequate human resources in quantity. In terms of quantity, Indonesia has a potential population of man power, but in terms of quality, it still takes time to process it.

\section{CONCLUSION}

From the results of research and discussion, it can be concluded that athlete breeding can be done by carrying out talent identification and then continuing with the talent development stage. This method is expected to make the nursery process better. 


\section{Evaluation in Sports Achievement Development: Literature Review}

The nursery system used in the concept of sports coaching is a nursery system that is able to become the foundation of achievement development. A good foundation is at school age where educational sports are important to give birth to athlete seeds.

\section{REFERENCES}

1) Ayu Reza Adzalika, Soegiyanto, R. (2019). Evaluasi Pembinaan Prestasi Atlet Cabang Olahraga Terukur (Atletik, Angkat Besi, Panahan dan Renang) Di Provinsi Lampung. Journal of Physical Education and Sport, 8(1), 56-61.

2) Connie Chairunnisa. (2011). Evaluasi Program Pendidikan dan Pengembangan Instrument. Jurnal Pendidikan Dan Kebudayaan, 2, 81-168.

3) Hakan, K., \& Seval, F. (2011). CIPP evaluation model scale: Development, reliability and validity. Procedia - Social and Behavioral Sciences, 15, 592-599. https://doi.org/10.1016/j.sbspro.2011.03.146

4) Helen Purnama Sari, O. W. K. H. \& T. H. (2017). Evaluasi Program Pembinaan Atlet Pekan Olahraga Nasional Cabang Olahraga Bulu Tangkis Provinsi Sumatera Selatan. Journal of Physical Education and Sports, 6(3), 261-265.

5) Herliandry, L. D., Nurhasanah, N., Suban, M. E., \& Kuswanto, H. (2020). Pembelajaran Pada Masa Pandemi Covid-19. JTP - Jurnal Teknologi Pendidikan, 22(1), 65-70. https://doi.org/10.21009/jtp.v22i1.15286

6) Jian Andri Kurniawan, Hari Amirullah Rahman, \& Soegiyanto, K. S. (2015). Journal of Physical Education and Sports. $4(1), 8-13$.

7) Meiyanto, A., Nasuka, \& Pramono, H. (2018). The Evaluation of The Founding Program of Badminton Clubs Aged 10-11 Years in Semarang City. JPES (Journal of Physical Education and Sports), 7(3), 260-266.

8) Satria, M. H., \& Muba, B. (2012). Evaluasi Program Pembinaan Olahraga Sepakbola Di Sekayu Youth Soccer Academy (Sysa) Kabupaten Musi Banyuasin Sumatera Selatan. Journal of Physical Education and Sports, 1(2).

9) Stufflebeam, D. C., \& Coryn. (2014). Evaluation Theory, Models,\& Applications. In Jossey-Bass (Vol. 2, Issue 3). JosseyBass.

10) Stufflebeam, D. L. (2015). CIPP evaluation model checklist: A tool for applying the CIPP model to assess projects and programs: Evaluation Checklists Project. 1-51.

11) Suharsimi Arikunto, C. S. A. J. (2010). Evaluasi Program pendidikan: Pedoman Teoretis Praktis bagi Mahasiswa dan Praktisi Pendidikan. PT Bumi Aksara.

12) Tangkudung, J. (2018). Metodologi Penelitian Kajian Dalam Olahraga (Issue October).

13) Tayibnapis, F. Y. (2008). Evaluasi Program dan Instrumen Evaluasi untuk Program Pendidikan dan Penelitian. Rineka Cipta.

14) Topno Harshit. (2012). Evaluation of Training and Development: An analysis of Various Models. IOSR Journal of Business and Management, 5, 16-22.

15) Zapata, A. (2015). The National Service Training Program of State Colleges and Universities : An Assessment. OALib, 02, $1-9$. 